\title{
POSTMENOPAUSAL BLEEDING;
} AN EXPERIENCE AT BAHAWAL VICTORIA HOSPITAL, BAHAWALPUR

\author{
DR. SHAKILA YASMIN \\ DR. NAHEED FATIMA \\ DR. TASNIM ZARFISHAN
}

\section{A B S T R A C T}

Objective : To evaluate the etiology, incidence of malignancy and interval between menopause and onset of abnormal vaginal bleeding in postmenopausal women. Design: Prospective study. Place And Duration of Study: The study was conducted at Bahawal Victoria Hospital, Bahawalpur for a period of 14 months (February 2002 to March 2003). Subjects: Thirty five cases of postmenopausal bleeding. Methods: A detailed history was taken followed by a detailed general physical, abdominal, pelvic and per-rectal examination. Cervical pap smear was done in all the patients except those with obvious cervical growth. Besides routine laboratory work, abdominal ultrasonography was done in all the cases. All patients were invariably subjected to fractional curretage and cervical biopsy was taken where indicated. Results: Malignancy was found to be the most common cause $(51.42 \%)$ of postmenopausal bleeding. Carcinoma of the cervix was commonest and found in $34.28 \%$, carcinoma of endometrium in $11.42 \%$, atrophic endometrium in $11.42 \%$, polyps in $8.57 \%$, chronic cervicitis in $8.57 \%$, endometrial hyperplasia in $5.71 \%$, carcinoma of ovary in $2.85 \%$, liomyosarcoma in $2.85 \%$, senile vaginitis, trauma, and forgotten IUCD each in $2.85 \%$ of cases. Etiology remained undetermined in $5.71 \%$ cases. Malignancy was directly related to years of clear span and was $88.88 \%$ in cases presenting 10 years or more after the menopause. Conclusion: Carcinoma of cervix was the commonest cause of postmenopausal bleeding in our study. Screening programme for early detection of carcinoma of cervix at a pre-invasive stage is highly recommended.

KEY WORDS: $\quad$ Postmenopausal bleeding, Etiology, carcinoma, malignancy

\section{INTRODUCTION}

Today, the life expectancy in women is longer, therefore, many will likely experience the postmenopausal period and postmenopausal bleeding accounts for approximately $5 \%$ of office visits to a general gynaecologist. ${ }^{1}$ Postmenopausal bleeding can be defined as bleeding, regardless of amount, from genital tract after one or more years of menopause, in a women who is not taking HRT. ${ }^{2,3,4}$ There is no universally accepted definition of postmenopausal bleeding. One year without bleeding at appropriate time of life is the criterion for the menopause, most often applied. ${ }^{2}$

The general consensus is that postmenopausal bleeding should be considered malignancy until proven otherwise, despite the fact that abnormal pathology is found in only $15 \%$ of endometrial biopsies. ${ }^{5}$

The malignancies that most commonly cause this symptom are carcinoma of endometrium and cervix. Postmenopausal bleeding is observed in $75-80 \%$ of women with endometriai carcinoma and it is also associated with non-endometrial cancers, most common of these is carcinoma of cervix. ${ }^{6,7,8,9}$. Every possible measure should be adopted to rule out malignancy as endometrial carcinoma has a much higher cure rate if diagnosed early. ${ }^{4}$ Information regarding the prevalence of malignant tumors in Pakistan is sketchy at the moment. There is no formal tumour registry system and 
little data is available apart from hospital based studies. So, this study was designed and conducted to determine the etiology of post menopausal bleeding in patients attending a tertiary hospital at Bahawalpur.

\section{MATERIAL \& METHODS}

All the patients in which primary complaint was postmenopausal bleeding, admitted in Gynecology and Obstetrics Unit-11 of Victoria Hospital Bahawalpur from February 2002 to March 2003, were enrolled. The study was limited to women falling in the age group of 45 years or more and whose bleeding started at least one year or more after cessation of menstruation. The exclusion criteria was based upon:

1) Women with extragenital origin of bleeding i.e. from bladder, urethra, rectum and anus.

2) Women who were taking hormone replacement therapy. A detailed history of each patient was taken followed by general physical, abdominal, pelvic and per-rectal examinations and data so collected was recorded on specialized performa. Results were collected and analysed at the end of 14 months.

Besides routine laboratory work including complete blood examination, complete urine examination, blood sugar, urea, creatinine, chest $x$-ray and ECG, (electocardiogram), abdominal ultrasonography (USG) was done especially to localize any ovarian tumour and endometrial thickness. Cervical pap smear was taken in most of the patients except for those who were having obvious cervical growth. It is a routine in our unit to book all the patients of postmenopausal bleeding for endometrial biopsy. So, all the patients were invariably subjected to fractional curretage and cervical biopsy was taken where indicated. It was followed by laparotomy or hysterectomy and bilateral salpingo-Oophorectomy as and when required. Patients requiring radiotherapy were referred to BINO (Bahawalpur Institute of Nuclear Medicine \& Oncology).
The average age of patients was 59.1210 .14 years. Malignancy was the most common cause of postmenopausal bleeding, in our study, and was detected in $18(51.42 \%)$ cases. Out of these total malignant cases, above $70 \%$ were between $66-85$ years. (Table-I).

\begin{tabular}{|c|c|c|c||}
\hline \multicolumn{4}{|c|}{ Table-1 Incidence of malignancy in relation to age } \\
\hline Age (years) & $\begin{array}{c}\text { No of } \\
\text { Cases }\end{array}$ & Malignant & Malignancy \% \\
\hline $45-55$ & 17 & 07 & 41.17 \\
\hline $56-65$ & 07 & 03 & 42.85 \\
\hline $66-75$ & 07 & 05 & 71.42 \\
\hline $76-85$ & 04 & 03 & 75.00 \\
\hline Total & 35 & 18 & 51.42 \\
\hline
\end{tabular}

Malignancy was directly related to years of clear span and was $88.88 \%$ in cases presenting 10 years or more after the menopause!. (Table-II).

\begin{tabular}{||c|c|c|c||}
\hline \hline \multicolumn{2}{||c|}{ Table-1I Incidence of malignancy in relation to clear span } \\
\hline $\begin{array}{c}\text { Clear span } \\
\text { (years) }\end{array}$ & $\begin{array}{c}\text { No of } \\
\text { Cases }\end{array}$ & Malignant & Malignancy $\%$ \\
\hline $1-5$ & 15 & 04 & 26.66 \\
\hline $6-10$ & 11 & 07 & 63.63 \\
\hline $10 \&$ above & 09 & 08 & 88.88 \\
\hline
\end{tabular}

Out of total 35 patients, malignancy was the cause of postmenopausal bleeding in 18 cases (51.42\%). Benign lesions were found in $15(42.85 \%)$ cases, while cause remained undetermined in 2 patients (5.71\%). (Table-III).

\begin{tabular}{||c|c|c||}
\hline \multicolumn{3}{|c||}{ Table-1II Type of lesion } \\
\hline Types of lesion & No of Cases & Malignant \\
\hline Malignant & 18 & 51.42 \\
\hline Benign & 15 & 42.85 \\
\hline
\end{tabular}

\section{RESULTS}




\begin{tabular}{||l|l|l|}
\hline Undetermined & 02 & 5.71 \\
\hline
\end{tabular}

In the group of malignant causes, carcinoma of cervix was the neoplasia most often detected (34.28\%) and endometrial carcinoma was next affecting (11.42\%). No patient with carcinoma of vulva or vagina was reported during the study period. Ovarian carcinoma and liomyosarcoma were present, each in one case. (2.85\%).

\begin{tabular}{|c|c|c|}
\hline \multicolumn{3}{|c|}{ Table-IV. } \\
\hline Cases & No. Of Cases & $\%$ age \\
\hline \multicolumn{3}{|l|}{ Malignant } \\
\hline $\begin{array}{l}\text { Carcinoma of } \\
\text { cervix }\end{array}$ & 12 & $34-28$ \\
\hline $\begin{array}{l}\text { Carcinoma of } \\
\text { endometrium }\end{array}$ & 04 & $11-42$ \\
\hline $\begin{array}{l}\text { Carcinoma of } \\
\text { vulva vagina }\end{array}$ & - & - \\
\hline $\begin{array}{l}\text { Carcinoma of } \\
\text { ovary }\end{array}$ & 01 & 2.85 \\
\hline Limosarcoma & 01 & 2.85 \\
\hline \multicolumn{3}{|l|}{ Benign } \\
\hline $\begin{array}{l}\text { Atrophic } \\
\text { endometrium }\end{array}$ & 04 & 11.42 \\
\hline Polyps & 03 & 8.57 \\
\hline Chronic cervicitis & 03 & $8 . .57$ \\
\hline $\begin{array}{l}\text { Endometrial } \\
\text { hyperplasia }\end{array}$ & 02 & 5.71 \\
\hline Senile vaginitis & 02 & 5.71 \\
\hline Trauma & 01 & 2.85 \\
\hline $\begin{array}{l}\text { Forgotton IUCD } \\
\text { (Lippe's loop) }\end{array}$ & 01 & 2.85 \\
\hline Undetermined & 02 & 5.71 \\
\hline
\end{tabular}

Table-V Associated clinical features.

\begin{tabular}{||l|c|c||}
\hline Clinical feature & No. Of Cases & \% age \\
\hline Anemia & 28 & 80 \\
\hline Low backache & 26 & 74.2 \\
\hline Hot flushes & 25 & 71.4 \\
\hline $\begin{array}{l}\text { Body aches \& } \\
\text { painful joints }\end{array}$ & 24 & 68.5 \\
\hline $\begin{array}{l}\text { Irritability \& } \\
\text { depression }\end{array}$ & 18 & 51 \\
\hline $\begin{array}{l}\text { Headaches \& } \\
\text { palpitations }\end{array}$ & 19 & 54.2 \\
\hline Vaginal discharge & 10 & 28.5 \\
\hline Hypertension & 09 & 25.7 \\
\hline \begin{tabular}{l} 
Diabetes Mellitus \\
\hline $\begin{array}{l}\text { Uterovaginal } \\
\text { prolapse }\end{array}$
\end{tabular} & 05 & 14.2 \\
\hline Abdominal mass & 01 & 8.57 \\
\hline
\end{tabular}

*Patients had more than one clinical features

Among the benign lesions, atrophic endometrium was the most common cause, $(11.42 \%)$ followed by polyps $(8.57 \%)$ and chronic cervicitis (8.57\%). Senile vaginitis, trauma (coital) and forgotten lippes' loop were seen each in one case $(2.85 \%)$. (Table-IV).

Most of the patients presented with multiple clinical features, detailed in table-V. Anemia was present in $80 \%$ of the patients. Low backache (74.2\%) and hot flushes $(71.4 \%)$ were the commonest menopausal symptoms followed by bodyaches and painful joints. (68.5\%). More than $50 \%$ of women complained of depression, irritability, palpitations and headaches. (Table-V).

\section{DISCUSSION}

Postmenopausal bleeding is a symptoms of varied etiologies including both benign and malignant conditions. In our study, we found malignant cases in $18(51.42 \%)$, benign in $15(42.85 \%)$ and pathology 
remained undetermined in 2 cases $(5.71 \%)$. The malignancy rate in our study is quite high as compared with recent literature. Although, Lee $\mathrm{WH}^{10}$ had reported an incidence of $42 \%$ but more recently Gredmerk $^{7}$ had showed overall malignancy rate of $10.3 \%$ only. However, situation has not changed in our part of word and incidence of malignancy as a cause of postmenopausal bleeding still remains high, as reported $53.71 \%$ by Nagina Fatima ${ }^{11}$ and $44 \%$ by Asif $\mathrm{KH}^{12}$ Panda et al ${ }^{13}$ from India had also reported an incidence of $63.6 \%$. So, our finding of high rale of malignancy is quite comparable with other authors in our region.

The commonest cause among the malignant lesions was carcinoma of cervix. (34.28\%). This figure is much higher as compared to incidence of $1.3 \%$ reported recently by Gredmark. ${ }^{7}$ This shows lack of screening programme in our society and failure on the part of patients also who neglected their symptoms and presented in late stage of disease, because of ignorance and illiteracy. Carcinoma of the endometrium was found in $4(11.42 \%)$ cases. The figure is comparable with a large multicentric study by Karlsson $^{9}(10 \%)$ and a local study ${ }^{11}(10.6 \%)$. However, Gredmark $^{7}$ had shown an incidence of 8.1 their increasing awareness of the importance of postmenopausal bleeding with all women referred for investigations rather than just those at high risk. Liomyosarcoma of uterus is a rare but highly malignant tumour with poor prognosis. Its incidence is approximately $2 / 100,000$ women over 20 years. ${ }^{14}$ We found one patient during the 14 months. Granulosa cell tumours of ovary is an important but rare cause of postmenopausal bleeding. Malmstorm et $\mathrm{al}^{15}$ in their study of 54 cases, have reported 26 such cases, but we found only one patient. No patient with carcinoma of vulva or vagina was reported during the study period (14 months). This wide variation in the reported incidences of malignancies responsible for postmenopausal bleeding, reflects variability in the types of patients who were studied, and the method of evaluation.

Benign lesions as a cause of postmenopausal bleeding were found in 15 cases (42.85\%). Atrophic endometrium was the most common cause (11.42\%) followed by
Polyps (8.57\%) and chronic cervicitis (8.57\%). Endometrial hyperplasia is considered to be a precursor of carcinoma and was found in $5.71 \%$ in the present study which is lower than other studies. ${ }^{7,12}$ Atrophic endometrium is reported to be the commonest cause of postmenopausal bleeding in the world literature, ${ }^{16,17}$ while in our study figure is much lower. In the present series, pathology remained undetermined in 2 cases $(5.71 \%)$, which is lower than $14 \%$ as reported by Gredmark et al. ${ }^{7}$ Most recently (2003) a study has shown that postmenopausal bleeding incurs a 64 fold increased risk for endometrial cancer. ${ }^{18}$ So, a women in whom no cause for postmenopausal bleeding is found, should have repeat investigatk ns after persistent or recurrent uterine bleeding and in some rare cases, a hysterectomy should be considered if a diagnosis cannot be made. ${ }^{19}$

\section{CONCLUSION}

We conclude that among malignant lesions the most common cause of postmenopausal bleeding in our set up is carcinoma of cervix. We recommend screening programmes for early detection of carcinoma of cervix at pre-invasive stage. Moreover, postmenopausal bleeding calls for immediate investigations, even though there is a single episode, because it could be a sign of endometrial cancer which has a much higher cure rate if diagnosed early.

\section{REFERENCES}

1. Dubinsky TJ, Parvey HR, Maklad N. The role of transvaginal sonography and endometrial biopsy in the evaluation of peri and postmenopausal bleeding. AJR AmJRoentgenal. 1997:169:145.

2. Procope BJ. Aetiology of postmenopausal bleeding. Acta Obstet Gynecol Scand. 1971: 50(4): 311-13.

3. Davey DA. The menopause and climacteric. Dehurst Textbook of Obstetrics \& Gynecology for postgraduates, $5^{\text {th }}$ ed. 1995:609-41.

Anne L. Mousey MD. Postmenopausal bleeding......

4.

Evaluation and management. Clinics in Family practice Volume. 4 Number 1. March 2002. 
5. Mc Gregor HF. Postmenopausal bleeding: A practical approach. J Am Acad Nurse Pract. 2001 Marc, 13(3): 11315.

6. Sirjusingh A, Bassaw B, Roopnarinesingh S, Ali A. Risk factors and treatment of endometrial carcinoma. West Indian Med J. 1993; 42(4): 147-48.

7. Gredmark T. Kvint S, Havel G, Mattsson LA Histopathological findings in women with postmenopausal bleeding. Br J Obset Gynecol. 1995; 102(2): 133-36

8. Granberg S, Wikland M, Karlsson B, Norstrom A, Friberg LG. Endometrial thickness as measured by endovaginal ultrasonography for identifying endometrial abnormality. Am J Obste Gynecol. 1991; 164: 47-52.

9. Karlsson B, Granberg S,Wikland M et al.

Transvaginal ultrasound of the endometrium in women with postmenopausal bleeding........ A Nordic multi center study. Am J Obstet Gynecol. 1995; 172:1488-93.

10. Lee-WH, Tan-KH, Lee YWT. Cytology of postmenopausal bleeding, a study of 163 cases in Singapore. Jomee. Med

J. $1995 ; 3 C(2): 164-68$.

11. Nagina Fatima Liaquat, Khurshid Noorani. Causes of postmenopausal bleeding......A study of 328 cases. JCPSP. 2000; 10(4): 134-37.

12. Asif $\mathrm{KH}$, Samina Hamid. Causes of postmenopausal bleeding. Pak J Obstet Gynecol. 1997; 3 : 22-6.

13. Panda S, Panda SN, Sarangi RK, Hobeebullah S Postmenopausal bleeding. J Indian Med Assoc. 1977;68: (9): 185-88.

14. Quinn MA, Anderson MC. Malignant disease of the uterus. In: Shah RW, WP Sauker WP. (edi). Gynecology. $2^{\text {nd }}$ ed $1997 ; .544-45$.

15. Malmstorm H, Hogberg $\mathrm{T}$, Risberg B, Simonsen $\mathrm{E}$. Granulosa cell tumour of ovary. Prognostic factors and outcome. Gynecol Oncol. 1994; 54(1): 50-5.

16. Salem S. The uterus and adenexa. In: Rumack CM, Wilson SR, Charboneau JW, eds. Diagnostic ultrasound. St. Louis: Mosby-Year Book, 1998; p 535-40.

17. Brenner PF. Differential diagnosis of abnormal uterine bleeding. Am J Obstet Gynecol. 1996; 175: 766-69.

18. B Gull, B Karlsson, I Milson, S. Granberg: Can ultrasound replace dilatation and curettage? A longitudinal evaluation of postmenopausal bleeding and transvaginal sonogaphic measurement of the endometrium as predictors of endometrial cancer. Am J Obstet \& Gynecol. 2003; 186:2.

19. Thomes Ind. Managemtn of postmenopausal bleeding. Progress in Obstetrics and Gynaecology Volume 13,1998. P 361-73. 